\title{
On the history of Brasenia Schreb. in the European Pleistocene
}

\author{
Danuta Drzymulska ${ }^{1}$ (D)
}

Received: 15 May 2017 / Accepted: 31 October 2017 / Published online: 9 November 2017

(C) The Author(s) 2017. This article is an open access publication

\begin{abstract}
Brasenia Schreb. is a monotypic genus in the Cabombaceae, present nowadays on all continents except Europe and Antarctica. This thermophilous aquatic plant, which originated in the Tertiary, was a frequent element of aquatic plant life during the interglacial stages of the European Pleistocene. A systematic review of the palaeobotanical records of Brasenia pollen and seeds reveals its history in Europe from the Plio-Peistocene until the Eemian interglacial. Remains of Brasenia were typical for the climatic optima during each of these stages of the Pleistocene. In this paper the diversity of fossil Brasenia species is also shown. The most abundant and morphologically diverse seeds were found in sediments from eastern European sites. Brasenia species became extinct in Europe at the end of the last interglacial or at the beginning of the Weichselian glaciation. Different scenarios for their disappearance are proposed, including the specificity of the floral cycle, probable poor dispersal of seeds, or the scarcity of suitable water bodies for it to survive.
\end{abstract}

Keywords Brasenia - Europe $\cdot$ Pleistocene $\cdot$ Interglacial · Extinction of species

\section{Introduction}

Brasenia and Cabomba are rhizomatous aquatic perennials with floating leaf blades in the Cabombaceae family. These

Communicated by T. Litt.

Danuta Drzymulska

drzym@uwb.edu.pl

1 Department of Palaeobotany, Institute of Biology, University of Białystok, K. Ciołkowskiego 1J, 15-245 Białystok, Poland two genera are similar to members of the Nymphaeaceae, where they were placed previously. There are many difficulties in defining families within the Nymphaeales. Therefore, their taxonomic affiliation has changed, as they were an object of interest for numerous authors (Goleniewska-Furmanowa 1970; Takhtajan 1980; Cronquist 1981). Nowadays, however, the position of the Cabombaceae as an independent family, which includes the genera Cabomba and Brasenia, is not questioned among taxonomists (Podoplelova and Ryzhakov 2005).

Both the Cabombaceae and Nymphaeaceae families (Nymphaeales; water lilies) are among the oldest angiosperms. Phylogenetic analyses have identified them, together with four other small groups of flowering plants (Amborellaceae, Illiciales, Trimeniaceae, Austrobaileyaceae, the ANITA grade), as the first diverging lineages from the main branch of the angiosperm phylogenetic tree. According to Friis et al. (2001), the earliest evidence of water lilies, based on fossil floral structures and associated pollen, extends their history back to the early Cretaceous (125-115 Ma). However, it is more likely that these records have not been clearly distinguished from Illiciales, in which case the oldest unequivocal record of the order is that of the water lily flower from the earliest Upper Cretaceous (approximately $90 \mathrm{Ma}$ ) (Gandolfo et al. 2004). Regarding the splitting of the Cabombaceae and Nymphaeaceae, there is substantial fossil evidence that the two families were distinct by the early Tertiary (Dorofeev 1973, 1974; Collinson 1980). According to Löhne et al. (2008), such diversification of the Nymphaeales into three major lineages, Cabombaceae, Nuphar and the other Nymphaeaceae, took place during the Palaeocene. The existence of Cabombaceae species was confirmed by well-documented data from the late Palaeocene-earliest Eocene, like fossils of Brasenia, Sabrenia (Collinson 1980), Braseniella and Dusembaya (Dorofeev 1973). Interestingly, 
according to the molecular data, the two extant genera of Cabombaceae, Cabomba and Brasenia, are thought to have diversified during the Oligocene $(26.5 \pm 13.1 \mathrm{Ma})$, with limits of confidence spanning from the Upper Eocene into the Middle Miocene (Löhne et al. 2008). However, the indisputable fossil evidence indicates that these genera must be older.

The genus Brasenia (water-shield) is today represented only by B. schreberi J. F. Gmel. [B. purpurea (Michx.) Casp.], an aquatic perennial growing in acidic (Muenscher 1944) or slightly acidic waters (Lakela 1965). It occurs in shallow lakes and ponds, as well as slow streams in eastern Asia (Taiwan, Japan, Korea, Sumatra, the Amur region in the Far East, at the foot of the Himalaya), Australia, islands of Oceania, Africa (Angola, Zambia), the West Indies, and South, Central and North America (Osborn and Schneider 1988). In this latter locality, Brasenia is widely represented, with a range from Alaska to California and from Nova Scotia to Florida (Środoń 1987).

Despite being a flexible taxon with a native range extending from tropical to nearly boreal habitats, this genus does not occur in Europe nowadays. It was different in the past, which is evidenced by fossil remains, which have been found in European Tertiary sediments. Well-documented Brasenia fossils are known from the Eocene (> $33 \mathrm{Ma}$ ) (Collinson 1980). In fact, Brasenia was a common element of European freshwater vegetation from the Eocene to the Pleistocene (Dorofeev 1984; Mai 1995). However, probably at the end of the Eemian stage, about $115 \mathrm{ka}$, it became extinct in Europe. As before, there is a lack of a wider data set of past sites where Brasenia has been found in Europe. Some data were included by Dorofeev (1984) and Löhne et al. (2008). Therefore, this paper is intended to be a comprehensive review of Brasenia records in the European Pleistocene, with an indication of the sites where B. schreberi has been found, as well as other extinct species of this genus. This paper is also an attempt to gather information about the reasons for the extinction of Brasenia in Europe, which happened at the end of the last interglacial or at the beginning of the last glaciation.

\section{Pleistocene fossils of Brasenia in Europe}

The fossil record of Brasenia in the European Pleistocene has been compiled from published sources specifying the sites from where the remains were recovered, species (if possible), types of remains, and the stage of Pleistocene used in the quoted paper (Table 1). In some cases, to make orientation easier, synonyms of the stage names are given (in parentheses). Figure 1 shows the location of the Brasenia fossil finds, with records of different ages indicated with different symbols. The names of the Pleistocene stages were used by West (1968), Zagwijn (1996), Kondratiene (1996), Ber (2006), Lindner and Marks (2008), Molodkov and Bolikhovskaya (2010), Lindner et al. (2013), as well as Yakubovskaya et al. (2014). Correlation of these stages in different countries of Europe is given in Table 2.

Generally, fossil remains of Brasenia are known most of all from central and eastern parts of the European continent, and these are mostly Eemian sites (Fig. 1). The presence of this taxon in Pleistocene sediments is only sporadically recognised based on pollen grains (Table 1). In sediments of the Holsteinian interglacial pollen was identified from the Gort site in Ireland, as pollen of Brasenia cf. schreberi (Jessen et al. 1959) and from Krzyżewo, Poland (Ber et al. 1998). At the Valakampiai site in Lithuania, pollen of $B$. cf. borysthenica was detected in sediments correlated with the Snaigupele (Kärlich, Lubavian) interglacial (Molodkov et al. 2002), whereas Eemian sites with pollen of Brasenia are known from Belgium (B. schreberi species) (Verbruggen 1999), Imbramowice in Poland (B. schreberi species) (Mamakowa 1989), Satiki in Latvia (Kalnina et al. 2007), and the Stora Gäddevik site in Sweden (Lemdahl et al. 2013). In these two latter sites pollen was assigned only to the genus. Even such identification seems to be a rarity. Both the not very characteristic exine and its poor resistance to acetolysis could be responsible for this (Walker 1976). Leaves and leaf-traces similar to those of Brasenia are even rarer finds, and their identification is usually based on the fact that in the same sediment samples seeds of Brasenia were also found (Środoń 1935). The seeds are very characteristic. They are ovoid, and their apex has a pyramidal structure with a central micropyle (pore). Thanks to these features they are definitely the most often identified remains of this genus. Therefore, the distinction of fossil species was almost exclusively based on the characteristics of seeds. Analysis of seeds concerns their size, morphology and anatomical details of seed coat sections. A detailed overview of the Pleistocene flora, including Brasenia, was presented by Velichkevich (1977, 1979, 1982) and Velichkevich and Zastawniak (2008). These studies covered central and eastern Europe, mainly Belarus and western Russia, but also Lithuania and Poland (Fig. 1). According to these papers, during the Pleistocene the following species occurred in this area: Brasenia belorussica $\mathrm{T}$. V. Jakub., B. holsatica (Web.) Weberb. and B. borysthenica Wieliczk. Additionally, the latter species was described in a few varieties: $B$. borysthenica Wieliczk. var. borysthenica Wieliczk., B. borysthenica Wieliczk. var. dvinensis Wieliczk., B. borysthenica Wieliczk., var. heterosperma Wieliczk. and $B$. borysthenica Wieliczk. var. nemensis Wieliczk.

Interestingly, the diagnostic features of seeds of the above-mentioned species are similar to those noted for Tertiary taxa. Velichkevich and Zastawniak (2008) stated the similarity of B. belorussica T. V. Jakub. and B. borysthenica Wieliczk. var. borysthenica Wieliczk. to Pliocene 
Table 1 Records of Pleistocene remains of Brasenia in Europe

\begin{tabular}{|c|c|c|c|c|}
\hline Locality/site & Site no & Remain type/taxon & Stage of Pleistocene & References \\
\hline England, East Midlands/Wing & 1 & Seeds/B. schreberi & Ipswichian (Eemian) & Hall (1978) \\
\hline Netherlands, south-west region/Zuurland & 2 & Seeds/B. schreberi & Eemian & Kuijper (1988) \\
\hline Netherlands, centre/Raalte & 3 & Seeds/B. schreberi & Eemian & van der Ham et al. (2008) \\
\hline Netherlands, north/Vollenhove & 4 & Seeds/B. schreberi & Eemian & van der Vlerk and Florschütz (1953) \\
\hline Belgium, north & 5 & Pollen?/B. schreberi & Eemian? & Verbruggen (1999) \\
\hline Germany, east/Grabschütz & 6 & Seeds/B. schreberi & Eemian & Mai (1990a) \\
\hline Germany, east/Neumark-Nord & 7 & Seeds/B. schreberi & Eemian & Mai (1990b, 2010) \\
\hline Germany, east/Klinge & 8 & Seeds/Brasenia & Eemian & Weber (1893) \\
\hline Germany, north-west & 9 & Seeds/B. schreberi & Eemian & Jessen and Milthers (1928) \\
\hline $\begin{array}{l}\text { Denmark, Jylland/Herning, Nørbølling, } \\
\text { Solsø }\end{array}$ & $10-12$ & Seeds/B. schreberi & Eemian & Jessen and Milthers (1928) \\
\hline Sweden, south/Småland & 13 & $\begin{array}{l}\text { Pollen, seeds/B. schrebe- } \\
\quad r i\end{array}$ & Eemian & Lemdahl et al. (2013) \\
\hline $\begin{array}{l}\text { Poland, west/Rusinów (formerly Rinners- } \\
\text { dorf) }\end{array}$ & 14 & Seeds/B. schreberi & Eemian & Stark et al. (1932) \\
\hline $\begin{array}{l}\text { Poland, centre/Dzbanki Kościuszkowskie, } \\
\text { Szczerców, Bedlno }\end{array}$ & $15-17$ & Seeds/B. holsatica & Eemian & Velichkevich et al. (2005) \\
\hline Poland, north-east/Bohoniki & 18 & Seeds/B. schreberi & Eemian & Kupryjanowicz et al. (2015) \\
\hline Poland, north-east/Smolniki & 19 & Seeds/B. schreberi & Eemian & Borówko-Dłużakowa (1971) \\
\hline Poland, south/Jaworzyna Śląska & 20 & Seeds/B. schreberi & Eemian & Kuszell (1980) \\
\hline Poland, south/Imbramowice & 21 & $\begin{array}{l}\text { Pollen, seeds } / B \text {. } \\
\text { schreberi }\end{array}$ & Eemian & Mamakowa (1989) \\
\hline Poland, centre/Władysławów & 22 & Seeds/B. schreberi & Eemian & Tobolski (1988) \\
\hline $\begin{array}{l}\text { Belarus, south-east/Loev, } \\
\text { west/Bogatyrevichi }\end{array}$ & 23,24 & Seeds/B. holsatica & Eemian & Velichkevich and Zastawniak (2008) \\
\hline Russia, west/Valdai Upland & 25 & Seeds/B. holsatica & Mikulino (Eemian) & Zyuganova (2009) \\
\hline Russia, East European Plain/Cheremoshnik & 26 & Seeds, fr./Brasenia & Eemian & Novenko et al. (2005) \\
\hline Lithuania, east/Medininkai & 27 & Seeds/B. holsatica & Eemian & Šeirienè et al. (2014) \\
\hline Lithuania, south/by Nemunas river & 28 & Seeds/B. holsatica & Merkinè (Eemian) & Baltrūnas et al. (2013) \\
\hline Latvia, west/Satiki & 29 & Pollen, seeds Brasenia & Eemian & Kalnina et al. (2007) \\
\hline Lithuania, east/Valakampiai & 30 & $\begin{array}{l}\text { Pollen/B. cf. borystheni- } \\
\qquad a\end{array}$ & $\begin{array}{l}\text { Snaigupele (Lubavian, } \\
\text { Kärlich) }\end{array}$ & Molodkov et al. (2002) \\
\hline Germany, west (Middle Rhine)/Kärlich & 31 & Seeds/B. holsatica & Kärlich & Bittmann (1992) \\
\hline Ireland, west/Gort & 32 & Pollen/B. cf. schreberi & $\begin{array}{l}\text { Mindel-Riss (Holsteinian, } \\
\text { Mazovian) }\end{array}$ & Jessen et al. (1959) \\
\hline England, south/Denham & 33 & Seeds/B. schreberi & Hoxnian (Holsteinian) & Gibbard et al. (1986) \\
\hline Netherlands, centre/Loosdrecht & 34 & Seeds/Brasenia & Mindel-Riss (Holsteinian) & Florschütz and Jonker (1942) \\
\hline Poland, north-east/Krzyżewo & 35 & Pollen/Brasenia & Mazovian (Holsteinian) & Ber et al. (1998) \\
\hline Poland, east/Dobropol & 36 & Seeds/ $B$. borysthenica & Mazovian (Holsteinian) & Hrynowiecka et al. (2014) \\
\hline Poland, east/Nowiny Żukowskie & 37 & Seeds/ $B$. borysthenica & Mazovian (Holsteinian) & Hrynowiecka and Winter (2015) \\
\hline $\begin{array}{l}\text { Poland, centre /Olszewice, east/Ciechanki } \\
\text { Krzesimowskie, south/Stanowice }\end{array}$ & $\begin{array}{c}38,39 \\
40\end{array}$ & $\begin{array}{l}\text { Seeds/B. borysthenica, } \\
\text { Brasenia }\end{array}$ & Mazovian (Holsteinian) & Velichkevich et al. (2004) \\
\hline Belarus & 41 & Seeds/ $B$. borysthenica & $\begin{array}{l}\text { Mazovian (Holsteinian, } \\
\text { Alexandryan) }\end{array}$ & Velichkevich and Zastawniak (2008) \\
\hline Latvia, west/Pulvernieki & 42 & Seeds/ $B$. borysthenica & $\begin{array}{l}\text { Pulvernieki (Mazovian, } \\
\text { Holsteinian) }\end{array}$ & Zelčs et al. (2011) \\
\hline Poland, east/Wylezin & 43 & Seeds/B. cf. holsatica & Mazovian (Holsteinian) & Velichkevich et al. (2004) \\
\hline Poland, east/Łuków & 44 & Seeds/ $B$. borysthenica & $\begin{array}{l}\text { Sanian } 2 \text { (Elsterian 2) glacia- } \\
\text { tion }\end{array}$ & Stachowicz-Rybka (2015) \\
\hline Poland, east/Łuków & 45 & $\begin{array}{l}\text { Seeds/B. borysthenica, } \\
\text { Brasenia }\end{array}$ & $\begin{array}{l}\text { Ferdynandovian } 2 \text { (Mogilev- } \\
\text { ian, Cromerian IV) }\end{array}$ & Stachowicz-Rybka (2015) \\
\hline Poland, centre/Ferdynandów & 46 & Seeds/ $B$. borysthenica & Ferdynandovian 2 & $\begin{array}{l}\text { Pidek et al. (2015); Stachowicz-Rybka } \\
\text { et al. (2017) }\end{array}$ \\
\hline Belarus, west/Nikolaevo & 47 & Seeds/ $B$. belorussica & $\begin{array}{l}\text { Borkovian (Ferdynandovian 1, } \\
\text { Cromerian III ) }\end{array}$ & Velichkevich and Zastawniak (2008) \\
\hline Belarus, Russia & 48,49 & Seeds/ $B$. borysthenica & Borkovian & Velichkevich and Zastawniak (2008) \\
\hline France, Alsace/Fort-Louis & 50 & Seeds/B. cf. schreberi & Waalian (Celestynovian) & Geissert (1979) \\
\hline Greece, Peloponnese/Megalopolis & 51 & Seeds/B. victoria & Early Pleistocene & Mädler (1971), Velitzelos et al. (2014) \\
\hline Russia, east/Nikolskoe & 52 & Seeds/Brasenia & Early Pleistocene & Dorofeev (1992) \\
\hline Czech Republic, west/Cheb basin & 53 & Seeds/B. cf. tanaitica & Plio-Pleistocene & Teodoridis et al. (2017) \\
\hline
\end{tabular}


B. tuberculata C. \& E. M. Reid. This species was widely distributed in Pliocene sediments of western Europe, Russia and Belarus, whereas the smaller seeds of $B$. borysthenica Wieliczk. var. heterosperma Wieliczk. are reminiscent of the seeds of Pliocene B. obovata Dorof. and B. pripiatensis Dorof. Importantly, these authors did not mention $B$. schreberi among Pleistocene species. The revision of the Pleistocene flora from several sites in Poland made by Velichkevich et al. $(2004,2005)$ showed a wrong identification of $B$. borysthenica seeds as those of $B$. schreberi. Therefore, there is a question whether other data from European sites are also incorrect, but because they have not been revised, this question cannot be answered. Concerning Brasenia species found in Pleistocene sediments, the occurrence of Brasenia cf. tanaitica Dorof. and B. victoria (Caspary) Weberbauer in lower Pleistocene layers, both Tertiary relics, must also be stressed (Table 1).

Generally, seeds of Brasenia have been found in Eemian interglacial sediments (Ipswichian, Mikulino, Merkinè), and less often in sediments of older interglacials, Waalian (Celestynovian), Ferdynandovian 1 (Borkovian, Cromerian III), Ferdynandovian 2 (Mogilevian, Cromerian IV), Holsteinian (Hoxnian, Mindel-Riss, Mazovian, Alexandryan, Pulvernieki), Kärlich (Snaigupele, Lubavian) (Table 1). At one site (Łuków, eastern Poland; Table 1; Fig. 1) seeds of Brasenia borysthenica were found in deposits correlated with a glacial sequence related to the early Sanian 2 (Elsterian 2) glaciation (Stachowicz-Rybka 2015). However, this seems to be only due to the re-bedding of older sediments, probably connected with the Ferdynandovian 2 interglacial, into the basin. There is a clear trend in the occurrence of certain Brasenia species in particular stages of the Pleistocene. For the Holsteinian interglacial $B$. borysthenica was a characteristic species; for the Eemian-B. schreberi and B. holsatica. However, seeds and pollen of Brasenia from western and northern Europe (the British Isles, The Netherlands, Belgium and Sweden) represent almost entirely B. schreberi, and are connected exclusively with Eemian sediments (Table 1). The second typical Eemian species, the now extinct $B$. holsatica, is known from sites in Belarus, Russia, Poland and Lithuania (Velichkevich and Zastawniak 2008). In Lithuania the occurrence of this species is scanty, whereas in Belarus tens of thousands of individuals representing these species have been found. Possibly, the northern boundary of $B$. holsatica distribution during the Eemian interglacial ran through Lithuania (Velichkevich 1982). Interestingly, seeds very similar to those of $B$. holsatica were also found in sediments of the Holsteinian (Mazovian) interglacial, in Wylezin (eastern Poland; Table 1; Fig. 1) (Velichkevich et al. 2004) and in the sediments of the Kärlich interglacial, in the German middle Rhine region (Table 1; Fig. 1) (Bittmann 1992).

\section{On the palaeoecology of Brasenia}

Brasenia species known from the European Pleistocene belonged to the thermophilous elements of the flora during several interglacials. In the Ferdynandovian 2 (Cromerian IV, Mogilevian) interglacial B. borysthenica occurred in shallow, warm waters as a component of the so-called Brasenia complex (Velichkevich 1977, 1979). The term means the association of thermophilous aquatic plants, like Nuphar lutea (L.) Sibth. \& Sm., Ceratophyllum demersum L., Myriophyllum spicatum L., M. verticillatum L., with the predominance of Brasenia, which were characteristic of the optimal climatic phases of this interglacial. In the Ferdynandów 2011 stratotype site, Brasenia is connected with another thermophilous taxon, Euryale ferox Salisb. (as well as in Kärlich, Bittmann 1992). Modern E. ferox can be found in tropical and subtropical zones of south-east Asia, where mean July temperatures attain $21{ }^{\circ} \mathrm{C}$. According to Stachowicz-Rybka et al. (2017), today this species has similar ecological tolerances as in the past.

During the Holsteinian interglacial B. borysthenica was still present in aquatic vegetation of shallow water. Regarding the trophic preferences of Brasenia there are different data. Its occurrence in acid water was stressed by Muenscher (1944) and Lakela (1965), while Mai (1985) described this genus as an indicator of eutrophic conditions. According to Hrynowiecka and Winter (2015), in Nowiny Żukowskie Brasenia occurred only with Aldrovanda dokturovskyi Dorof. (now an extinct carnivorous thermophilous plant) and Potamogeton natans L. Both B. borysthenica and (A) dokturovskyi were typical of the climatic optimum flora of the Holsteinian interglacial, whereas at the Dobropol site, besides (B) borysthenica, Najas flexilis (Willd.) Rostk. \& W.L.E. Schmidt, Stratiotes aloides L. and Myriophyllum spicatum were also present in the water body (Hrynowiecka et al. 2014).

The thermophilous character of Brasenia was also confirmed during the Eemian interglacial. In the optimal phase of the last interglacial, this plant was a regular component of the vegetation of shallow water bodies. According to Zyuaganova (2009), besides B. holsatica, this Brasenia assemblage could have been formed by Salvinia natans (L.) All., Nuphar lutea, Trapa natans L., Aldrovanda vesiculosa L., Dulichium arundinaceum (L.) Britt., or Caulinia flexilis Willd. The assemblage reflects the vegetation of shallow organic-rich water bodies, so-called lake-swamps, which existed in warm and mild climate conditions. The past plant communities with Brasenia, like Brasenia-Aldrovanda, Brasenia-Nuphar-Aldrovanda or Brasenia-Nymphaea, were also described (Mai 1985). In contrast, at the site of Wing, United Kingdom, B. schreberi represented a mire community encroaching on a lake with increasingly acid waters, perhaps with birch woodland in the drier parts and Taxus 
Fig. 1 Map of sites with Pleistocene Brasenia remains in Europe. Numbers as in Table 1

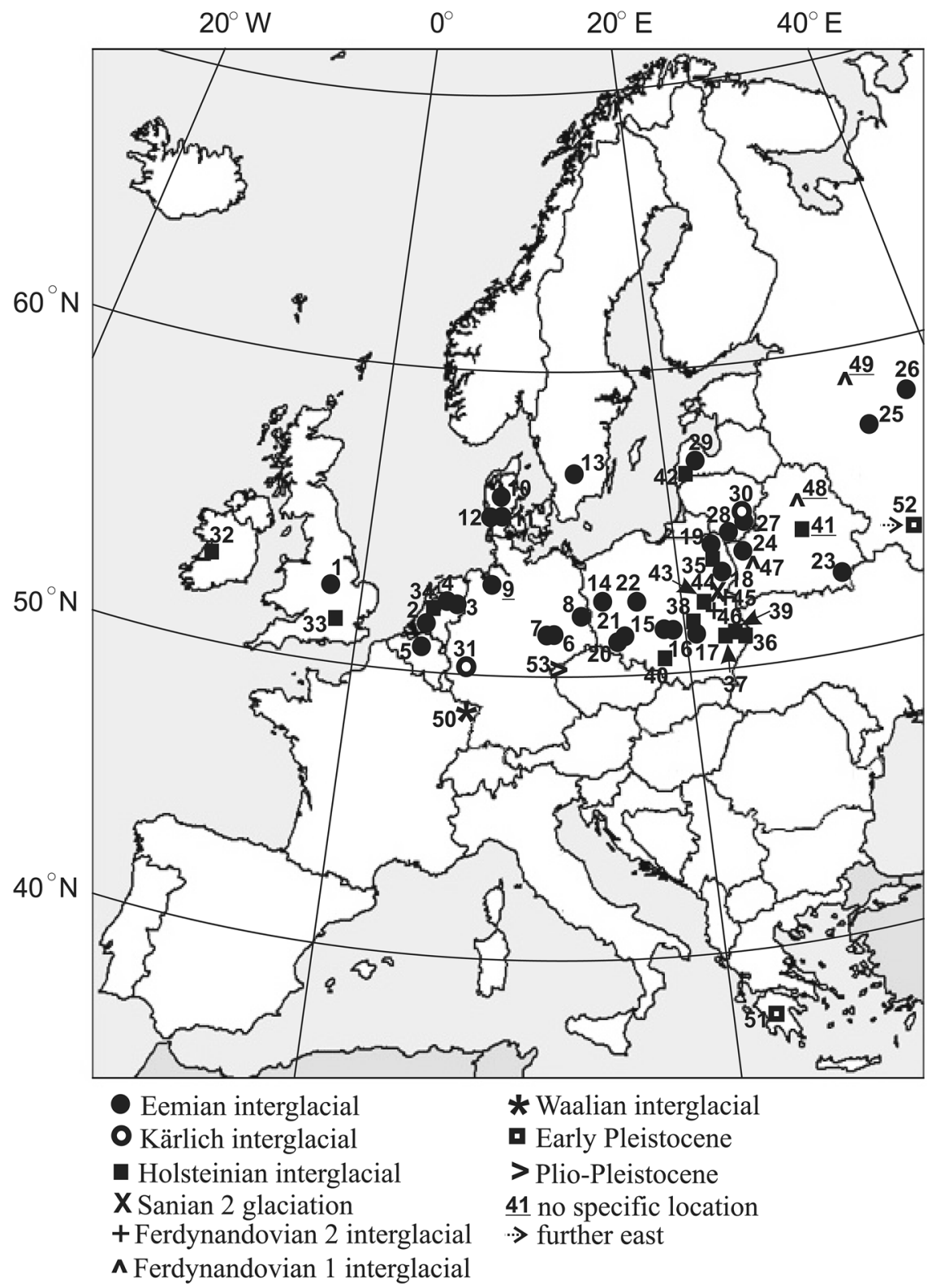

(yew) on the base-rich soils skirting the basin. Menyanthes, Carex spp., Eriophorum vaginatum L., and a number of mosses, notably Cratoneuron commutatum var. falcatum (Brid.) Mönk., Meesia longiseta Hedw. and species of Sphagnum accompanied it (Hall 1978). Brasenia schreberi is connected with such mildly acidic quiet and shallow (less than $1 \mathrm{~m}$ ) waters with floating mats of vegetation in North America nowadays. Nuphar, Nymphaea, Potamogeton, Utricularia vulgaris L. and Charophyta are associated with it (Birks 1973). This plant is seen to grow equally well in sub-arctic and tropical regions. Why then is it absent from Europe at present? Why were European populations, which were so numerous in the Pleistocene, not able to survive the last glaciation?
It is hard to disagree with Marie-Victorin and Léon (1944) that the disappearance of $B$. schreberi, which equally favours the cold lakes of Canada and the warm lagoons of Cuba and in America, and is seen to grow equally well in subarctic and tropical regions, cannot be attributed to climatic changes. Therefore, the reason for its extinction seems to lie in plant specificity. Wood (1959) points out that there is a difference in the mode of seasonal growth to accommodate this: in the northern parts of its range Brasenia overwinters as winter buds or turions, which are produced in autumn and fall to the lake bottom, and further south the plant is evergreen and reproduces more readily by seed. This ability to adapt to changing climate is clearly an advantage in a plant exposed to the climatic fluctuations of the Pleistocene. Raymond and Dansereau (1953) suggest that the overwintering 
Table 2 Correlation of the selected Pleistocene stages in European countries and regions

\begin{tabular}{ll}
\hline Poland & Other European countries/regions \\
\hline Eemian interglacial & Eemian/Eem (W/NW Europe) \\
& Ipswichian (England) \\
& Merkinè (Lithuania) \\
& Mikulino (Russia) \\
& Snajgupele (Lithuania) \\
Lubavian interglacial & Kärlich (Germany) \\
& Holsteinian (W/NW Europe) \\
Mazovian interglacial & Mindel-Riss (W Europe) \\
& Hoxnian (England) \\
& Pulvernieki (Latvia) \\
& Alexandryan (Belarus) \\
& Elsterian/Elster (W/NW Europe) \\
Sanian 2 glaciation & Cromerian III (W Europe) \\
Ferdynandovian 1 interglacial & Borkovian (Belarus) \\
Ferdynandovian 2 interglacial & Cromerian IV (W Europe) \\
& Mogilevian (Belarus) \\
Celestynovian interglacial & Waalian/Waal (W/NW Europe) \\
\hline
\end{tabular}

habit was, to some extent, responsible for the survival of this taxon as a relic of an "early Tertiary megaphyllous flora" in North America. European populations were probably unable to alter their growth mode. Therefore, the increasingly cold winters could have exterminated Brasenia, which was unable to produce overwintering turions instead of seeds. The lack of adaptations by European Brasenia, which are possessed by North American populations, could be the key to its extinction in Europe. According to Hall (1978), a further factor in explaining the extinction of Brasenia may be the possible lack of suitable glacial refugia for Eemian Brasenia in the southern part of the continent. Actually, the area of lakes in the interglacials was greater than nowadays. Such an abundance and extent of lakes resulting from the wet climate would have provided excellent conditions for $\mathrm{Bra}$ senia, while after the last glaciation, lake areas were much smaller. However, the same author did not entirely exclude the possibility that Brasenia occurred in Europe during the Weichselian glaciation. It could just have been isolated in the south and unable to migrate to the north at the beginning of the Holocene. The lack of any particular adaptation for the dispersal of the seeds of Brasenia by birds, such as hairs or spikes, did not help. However, according to Yoo et al. (2005), before its extinction in Europe this genus probably migrated with success southward, to Africa. Water lily seeds are an important food source for ducks and other diving waterfowl, so during bird migrations, which generally follow a north-south directional pattern (Berthold 1993), Brasenia seeds could have been transported to the south for a great distance. Such transport to the north was probably more questionable because of the mountain ranges in Europe.

The floral cycle of modern $B$. schreberi also provides information about some possible reasons for its extinction. Its flowers appear with one sex functioning at a time (dichogamous) (Osborn and Schneider 1988), first the functionally female flower (protogynous) (Thien et al. 2009) followed by its re-appearance as a functionally male one, and this is a mechanism for eliminating self-pollination. Maybe this feature was also present in Pleistocene Brasenia. However, at that time self-fertilisation (autogamy) could have been desirable as a way to survive in the conditions of a cooling climate at the beginning of the Weichselian glaciation. Unfortunately, it was not possible, and cross fertilisation (allogamy) or even cross pollination between different flowers on the same plant (geitonogamy) may have been impeded as a result of the weakness of the specimens (maybe the number of flowers was reduced) and the decrease in their numbers. Therefore, this is another possible contribution to the extinction of Brasenia.

\section{Conclusions}

In light of the palaeobotanical records of Brasenia from the Pleistocene sediments of Europe it was then an important component of aquatic plant life in Europe. As a thermophilous taxon which originated in the Tertiary, Brasenia managed to survive numerous glacial stages during the Pleistocene. However, the last one of them seemed to bring its history in Europe to an end. This curious fact of Brasenia extinction was undoubtedly caused by a combination of several factors. Its fate was shared by another Tertiary relic of the Pleistocene flora, Dulichium arundinaceum, which occurs only in North America nowadays, where it is a frequent constituent of vegetation around small lakes. Interestingly, as a component of floating mats (together with Lycopus uniflorus Michx., Menyanthes, Potentilla palustris (L.) Scop., Eupatorium maculatum L. and Sagittaria latifolia) it is found close by aquatic vegetation including Brasenia (Hall 1978). However, these two plants seem to be associated not only today, but were also in the past. This is confirmed by numerous macrofossil finds of Brasenia and Dulichium occurring together in sediments across Europe (Jessen and Milthers 1928; Hall 1978; Velichkevich 1982; Gibbard et al. 1986). Therefore, Brasenia is not the only known case of a puzzling extinction on the European continent.

Open Access This article is distributed under the terms of the Creative Commons Attribution 4.0 International License (http://creativecommons.org/licenses/by/4.0/), which permits unrestricted use, 
distribution, and reproduction in any medium, provided you give appropriate credit to the original author(s) and the source, provide a link to the Creative Commons license, and indicate if changes were made.

\section{References}

Baltrūnas V, Šeirienė V, Molodkov A et al (2013) Depositional environment and climate changes during the late Pleistocene as recorded by the Netiesos section in southern Lithuania. Quat Int 292:136-149

Ber A (2006) Pleistocene interglacials and glaciations of northeastern Poland compared to neighbouring areas. Quat Int 149:12-23

Ber A, Janczyk-Kopikowa Z, Krzyszkowski D (1998) A new interglacial stage in Poland (Augustovian) and the problem of the age of the oldest Pleistocene till. Quat Sci Rev 17:761-773

Berthold P (1993) Bird migration: a general survey. Oxford University Press, Oxford

Birks HH (1973) Modern macrofossil assemblages in lake sediments in Minnesota. In: Birks HJB, West RG (eds) Quaternary plant ecology. Blackwell, Oxford, pp 173-189

Bittmann F (1992) The Kärlich interglacial, Middle Rhine region, Germany: vegetation history and stratigraphic position. Veget Hist Archaeobot 1:243-258

Borówko-Dłużakowa Z (1971) The buried Eem Interglacial flora at Smolniki nearly Suwałki. Przegląd Geograficzny 43:591-598

Collinson ME (1980) Recent and Tertiary seeds of the Nymphaeaceae sensu lato with a revision of Brasenia ovula (Brong.) Reid and Chandler. Ann Bot 46:603-632

Cronquist A (1981) An integrated system of classification of flowering plants. Columbia University Press, New York

Dorofeev PI (1973) Systematics of ancestral forms of Brasenia. Paleontol J 2:212-227

Dorofeev PI (1974) Nymphaeales. In: Takhtajan A (ed) Magnoliophyta fossilia U.R.S.S, vol 1: Magnoliaceae-Eucommiaceae. Nauka, Leningrad, pp 52-88

Dorofeev PI (1984) The taxonomy and history of the genus Brasenia (Cabombaceae). Bot Zhurn 69:137-148

Dorofeev PI (1992) Nizhnepleystotsenovaya nadmorennaya semennaya flora opornogo razreza Nikol'skoe (Demshinsk) (The early Pleistocene overmoraine seed key flora site of Nikol'skoe (Demshinsk), in Russian). In: Velichko AA, Shik SM (eds) Stratigrafiya i paleogeografiya chetvertichnogo perioda vostochnoy Evropy (The stratigraphy and palaeogeography of the Quaternary of Eastern Europe, in Russian). Izadelstvo Instituta Geografii Rosiyskoy Akademii Nauk, Moskva, pp 199-245

Florschütz F, Jonker FP (1942) Über die Flora des Mindel-RissInterglazials in den Niederlanden. Recueil Trav Bot Neerl 39:176-188

Friis EM, Pedersen KR, Crane PR (2001) Fossil evidence of water lilies (Nymphaeales) in the Early Cretaceous. Nature 410:357

Gandolfo MA, Nixon KC, Crepet WL (2004) Cretaceous flowers of Nymphaeaceae and implications for complex insect entrapment pollination mechanisms in early angiosperms. Proc Natl Acad Sci USA 101:8,056-8,060

Geissert F (1979) Caractéristiques paléobotaniques du Pliocène et du Quaternaire en Basse-Alsace. Bull AFEQ 16:159-169

Gibbard PL, Bryant ID, Hall AR (1986) A Hoxnian interglacial doline infilling at Slade Oak Lane, Denham, Buckinghamshire, England. Geol Mag 123:27-43

Goleniewska-Furmanowa M (1970) Comparative leaf anatomy and alkaloid content in the Nymphaeaceae Bentham and Hooker. Monogr Bot 31:5-54
Hall A (1978) Some new palaeobotanical records for the British Ipswichian Interglacial. New Phytol 81:805-812

Hrynowiecka A, Winter H (2015) Palaeoclimatic changes in the Holsteinian Interglacial (Middle Pleistocene) on the basis of indicator-species method-palynological and macrofossils remains from Nowiny Żukowskie site (SE Poland). Quat Int 409:255-269

Hrynowiecka A, Żarski M, Winter H (2014) Vegetation and stratigraphy of the Mazovian (Holsteinian) interglacial sections from Dobropol and other new sites in Western Polesie Region, southeastern Poland. Stud Quat 31:17-30

Jessen K, Andersen ST, Farrington A (1959) The Interglacial deposit near Gort, Co. Galway, Ireland. In: Proceedings of the Royal Irish Academy, Section B: Biological, Geological and Chemical Science, vol 60. Hodges, Dublin, pp 1-77

Jessen K, Milthers V (1928) Stratigraphical and palaeontological studies of interglacial freshwater deposits in Jutland and Northwest Germany. (Danmarks geologiske Undersøgelse 48. Reitzel, Kopenhagen

Kalnina L, Strautnieksa I, Cerina A (2007) Upper Pleistocene biostratigraphy and traces of glaciotectonics at the Satiki site, western Latvia. Quat Int 164-165:197-206

Kondratiene O (1996) The Quaternary stratigraphy and paleogeography of Lithuania based on paleobotanic studies. Academia, Vilnius

Kuijper WJ (1988) Plant macrofossils of the borehole at Zuurland, Brielle, SW Netherlands (interim report of the section -5 to $-63 \mathrm{~m}$ ). Meded Werkgr Tert Kwart Geol 25:39-47

Kupryjanowicz M, Drzymulska D, Fiłoc M (2015) Eemian and early Weichselian Lobelia lakes in northeastern Poland. Rev Palaeobot Palynol 219:28-38

Kuszell T (1980) Trzy nowe stanowiska flory z interglacjału eemskiego na Dolnym Śląsku (Three new locations of the Eemian flora in the Lower Silesia, in Polish). Geol Sudetica 15:143-167

Lakela O (1965) A flora of Northeastern Minnesota. Minnesota Univ Press, Minneapolis

Lemdahl G, Broström A, Hedenäs L, Arvidsson K, Holmgren S, Gaillard MJ, Möller P (2013) Eemian and Early Weichselian environments in southern Sweden: a multi-proxy study of tillcovered organic deposits from the Småland peneplain. J Quat Sci 28:705-719

Lindner L, Marks L (2008) Pleistocene stratigraphy of Poland and its correlation with stratotype sections in the Volhynian Upland (Ukraine). Geochronometria 31:31-37

Lindner L, Marks L, Nita M (2013) Climatostratigraphy of interglacials in Poland: Middle and Upper Pleistocene lower boundaries from a Polish perspective. Quat Int 292:113-123

Löhne C, Yoo MJ, Borsch T, Wiersema J, Wilde V, Bell CD, Barthlott W, Soltis DE, Soltis PS (2008) Biogeography of Nymphaeales: extant patterns and historical events. Taxon 57:1,123-1,146

Mädler K (1971) Die Früchte und Samen aus der frühpleistozänen Braunkohle von Megalopolis in Griechenland und ihre ökologische Bedeutung. Beih Geol Jahrb 110:1-79

Mai DH (1985) Entwicklung der Wasser-und SumpfpflanzenGesellschaften Europas von der Kreide bis ins Quartär. Flora 176:449-511

Mai DH (1990a) Die Flora des Interglazials von Grabschütz (Kreis Delitzsch). Altenburger Naturwiss Forsch 5:116-137

Mai DH (1990b) Zur Flora des Interglazials von Neumark-Nord. In: Mania D, Thomae M, Litt T, Weber T (eds) Neumark-Gröbern: Beiträge zur Jagd des Mittelpaläolithischen Menschen. Veröffentlichungen des Landesmuseums für Vorgeschichte, Halle, pp 159-160

Mai DH (1995) Tertiäre Vegetationsgeschichte Europas. Fischer, Jena 
Mai DH (2010) Karpologische Untersuchungen in einem Interglazial von Neumark-Nord (Geiseltal). Palaeontogr Abt B 282(4-6):99-187

Mamakowa K (1989) Late Middle Polish Glaciation, Eemian and Early Vistulian vegetation at Imbramowice near Wroclaw and the pollen stratigraphy of this part of the Pleistocene in Poland. Acta Palaeobot 29:11-176

Marie-Victorin F, Léon F (1944) Itinéraires botaniques dans l'ile de Cuba. Contr Inst Biol Univ Montreal 50:134

Molodkov A, Bolikhovskaya N (2010) Climatochronostratigraphic framework of Pleistocene terrestrial and marine deposits of Northern Eurasia, based on pollen, electron spin resonance, and infrared optically stimulated luminescence analyses. Est $\mathrm{J}$ Earth Sci 59:49-62

Molodkov A, Bolikhovskaya N, Gaigalas A (2002) The last Middle Pleistocene interglacial in Lithuania: insights from ESR-dating of deposits at Valakampiai, and from stratigraphic and palaeoenvironmental data. Geol Q 46:363-374

Muenscher WC (1944) Aquatic plants of the United States. Comstock, Ithaca

Novenko E, Velichko AA, Suganova IS, Junge FW, Boettger T (2005) Dynamics of vegetation at the Late Pleistocene Glacial/Interglacial transition (new data from the center of the East European Plain). Pol Geol Inst Spec Pap 16:77-82

Osborn JM, Schneider EL (1988) Morphological studies of the Nymphaeaceae sensu lato. 16: the floral biology of Brasenia schreberi. Ann Missouri Bot Gard 75:778-794

Pidek IA, Stachowicz-Rybka R, Żarski M (2015) Nowe dane paleobotaniczne z profilu Ferdynandów 2011 na stanowisku stratotypowym (New palaeobotanical data from the Ferdynandów 2011 profile in the stratotype site, in Polish). Annales Universitatis Mariae Curie-Skłodowska Lublin 70:9-26

Podoplelova Y, Ryzhakov G (2005) Phylogenetic analysis of the order Nymphaeales based on the nucleotide sequences of the chloroplast ITS2-4 region. Plant Sci 169:606-611

Raymond M, Dansereau P (1953) The geographical distribution of the bipolar Nymphaeaceae, Nymphaea tetragona and Brasenia schreberi. In: Proceedings of the seventh pacific science congress, vol 7, no 5. Owen, Wellington, pp 122-131

Šeirienè V, Kühl N, Kisielienė D (2014) Quantitative reconstruction of climate variability during the Eemian (Merkinè) and Weichselian (Nemunas) in Lithuania. Quat Res 82:229-235

Środoń A (1935) Studies on diluvial plant remains of the family Nymphaeaceae. Starunia 7. Polska Akademija Umiejętności, Kraków

Środoń A (1987) Dlaczego Brasenia nie rośnie dziś w Polsce? (Why Brasenia does not grow in Poland today?) Wiad Bot 31:181-184

Stachowicz-Rybka R (2015) Record of environmental and climatic changes in middle Pleistocene sediments from Łuków (eastern Poland) on the basis of plant macroremains analysis. Acta Palaeobot 55:67-91

Stachowicz-Rybka R, Pidek IA, Żarski M (2017) New palaeoclimate reconstructions based on multidisciplinary investigation in the Ferdynandów 2011 stratotype site (eastern Poland). Geol Q 61:276-290

Stark P, Firbas F, Ovebeck F (1932) Die Vegetationsentwicklung des Interglazials von Rinnersdorf in der östlichen Mark Brandenburg. Leuwer, Bremen (Abh Naturwissen Ver Bremen 28)

Takhtajan A (1980) Outline for the classification of flowering plants (Magnoliophyta). Bot Rev 46:225-359

Teodoridis V, Bruch AA, Martinetto E, Vassio E, Kvaček Z, Stuchlik L (2017) Plio-Pleistocene floras of the Vildštejn Formation in the Cheb Basin, Czech Republic-a review and a new paleoenvironmental evaluation. Palaeogeogr Palaeoclimatol Palaeoecol 467:166-190

Thien LB, Bernhardt P, Devall MS, Chen Z, Luo Y, Fan JH, Yuan LC, Williams JH (2009) Pollination biology of basal Angiosperms (ANITA grade). Am J Bot 96:1-17
Tobolski K (1988) Biostratigraphical record of Vistulian deposits at the maximum extent of the last ice sheet in the Konin region, Poland. Geogr Pol 55:181-187

Van der Ham RWJM, Kuijper WJ, Kortselius MJH, van der Burgh J, Stone GN, Brewer JG (2008) Plant remains from the Kreftenheye Formation (Eemian) at Raalte, The Netherlands. Veget Hist Archaeobot 17:127-144

Van der Vlerk IM, Florschütz F (1953) The palaeontological base of the subdivision of the Pleistocene in The Netherlands. Verhandelingen Koninklijke Akademie van Wetenschappen, Afdeling Natuurkunde 1 20:1-58

Velichkevich F (1977) O verchnepliocenovych i nizneantropogenovych florach zapada Vostocno-Evropejskoj ravniny (On the Upper Pliocene and Lower Anthropogene floras of western part of EastEuropean Plain, in Russian). In: Levkov EA, Khursevich GK (eds) $\mathrm{O}$ granitse mezhdu neogenom i antropogenom [On the boundary between the Neogene and Anthropogene, in Russian]. Izdatelstvo Nauka i Tekhnika, Minsk, pp 251-269

Velichkevich F (1979) Istoria pleystotsenovoy flory sredney polosy Vostochno-Evropeyskoy ravniny (The history of the Pleistocene flora of intermediary area of the East-European Plain, in Russian). In: Goretskiy GI, Grichuk VP (eds) Sovetskaya paleokarpologiya (Soviet Palaeocarpology, in Russian). Izdatelstvo Nauka, Moskva, pp 76-121

Velichkevich F (1982) Pleystotsenovye flory lednikovykh oblastey Vostochno-Evropeyskoy ravniny (The Pleistocene floras of glacial areas of the East European Plain, in Russian). Izdatelstvo Nauka I Tekhnika, Minsk

Velichkevich F, Mamakowa K, Stuchlik L (2004) Revision of some Mazovian interglacial macrofossil floras of Poland. Acta Palaeobot 44:93-104

Velichkevich F, Mamakowa K, Stuchlik L (2005) Revision of some plant macrofossil collections from the Eemian interglacial deposits of central and western Poland. Acta Palaeobot 45:107-115

Velichkevich F, Zastawniak E (2008) Atlas of the Pleistocene vascular plant macrofossils of Central and Eastern Europe. Part 2: Herbaceous dicotyledons. W. Szafer Institute of Botany, Polish Academy of Sciences, Kraków

Velitzelos D, Bouchal JM, Denk T (2014) Review of the Cenozoic floras and vegetation of Greece. Rev Palaeobot Palynol 204:56-117

Verbruggen C (1999) Quaternary palaeobotanical evolution of northern Belgium. Geol Belg 2(3-4):99-110

Walker JW (1976) Comparative pollen morphology and phylogeny of the Ranalean complex. In: Beck CB (ed) Origin and early evolution of Angiosperms. Columbia University Press, New York and London, pp 241-299

Weber CA (1893) Über die diluviale Vegetation von Klinge in Brandenburg und über ihre Herkunft. Bot Jahrb Syst Pflanzengeogr 17 Beiblatt 40:1-20

West RG (1968) Pleistocene geology and biology. Longman, London

Wood CE (1959) The genera of the Nymphaeaceae and Ceratophyllaceae in the southeastern United States. J Arnold Arbor 40:94-112

Yakubovskaya TV, Litvinyuk GI, Motuzko AH (2014) Korchevskoye mezhlednikovye Belorussii (The Korchevo Interglacial in Belorussia. in Russian). Isdatiel V. Chursick, Minsk

Yoo MJ, Bell CD, Soltis PS, Soltis DE (2005) Divergence times and historical biogeography of Nymphaeales. Syst Bot 30:693-704

Zagwijn WH (1996) An analysis of Eemian climate in Western and Central Europe. Quat Sci Rev 15:451-469

Zelčs V, Markots A, Nartišs M, Saks T (2011) Pleistocene glaciations in Latvia. In: Ehlers J, Gibbard PL, Hughes PD (eds) Quaternary glaciations-extent and chronology. (Developments in quaternary science 15). Elsevier, Amsterdam, pp 221-229

Zyuganova IS (2009) Upper Pleistocene carpological assemblages from the South of the Valdai Upland. Paleontol J 43:1,351-1,362 